Where do I come from? Metaphors in Sex Education Picture Books for Young Children in China

Jennifer Yameng Liang ${ }^{\mathrm{a}}$, Kay O’Halloran ${ }^{\mathrm{b}}$, \& Sabine Tan $^{\mathrm{b}}$

${ }^{a}$ School of Foreign Studies, University of Science and Technology Beijing, No. 30 Xueyuan Road, Haidian District, Beijing 100083.

${ }^{\mathrm{b}}$ School of Education, Building 501, Curtin University, Kent Street, Bentley, Western Australia 6102.

(Address correspondence to Kay O’Halloran, School of Education, Building 501, Curtin University, Kent Street, Bentley, Western Australia 6102. Email: kay.ohalloran@curtin.edu.au; Tel: +61 (8)9266 2182) 


\section{Where do I come from? Metaphors in Sex Education Picture Books for Young Children in China}

This study examines the types of verbal, pictorial and multimodal metaphors in the genre of sex education picture books for young children in Mainland China. Although being an educational discourse genre that is essentially concerned with transmitting scientific facts, sex education picture books employ a range of metaphors that categorise and construe the biological knowledge of human reproduction in a way that not only facilitates young children's understanding of scientific concepts but also instils in them particular values and moralities that are socio-culturally conditioned. An examination of the source domains from which the metaphors are drawn and the target domain onto which the metaphors are mapped reveals three types of metaphor, namely, personification, domestication and cross-experience metaphors. The analysis of seven sex education picture books for pre-school children suggests that these types of metaphor are used purposefully for addressing pedagogical as well as ideological concerns in the introduction of sex-related knowledge in Mainland China.

\section{INTRODUCTION}

Metaphor, defined as figurative language which equates two unrelated concepts for rhetorical effect, is a powerful means for facilitating conceptualisation and understanding of ideas. Lakoff \& Johnson's (1980) pioneering work in cognitive approaches to metaphor highlights the association of metaphorical representations with an "experiential basis" (i.e. perceptions of the material world) that is commonly shared by participants in a culture. While Lakoff \& Johnson's framework of Conceptual Metaphor Theory was developed primarily for analysing 
linguistic metaphors, it has been extended by Forceville (e.g. 1994, 1996, 2009) and others (e.g. Forceville and Urios-Aparisi, 2009) to include pictorial and multimodal metaphors that examine the meaning making of non-verbal modes such as images. Widely applied to advertisements (e.g. Forceville, 1996), political cartoons (e.g. Chapters 7-10 in Forceville \& Urios-Aparisi, 2009), and some other genres, the theoretical frameworks of pictorial and multimodal metaphor have proved insightful for unravelling the kinds of socio-cultural knowledge construed by different genres (e.g. Morris, 1993).

In this paper, Forceville's $(1994,1996,2009)$ theoretical frameworks of pictorial and multimodal metaphor are drawn upon to account for the nature of metaphorical representations featured in seven sex education picture books for pre-school children in Mainland China. Furthermore, this exploratory study also focuses on the ways realities are construed, conceptualised and categorised by metaphorical representations so as to investigate how the socially sensitive subject of human reproduction is conveyed to young children. To that end, this paper draws upon Morris's (1993) formulation of the "processes of visual rhetoric" and extends the discussion of visual mode to the verbal and verbal/visual (i.e. multimodal) mode in order to develop a functional categorisation of the pictorial and multimodal metaphors found in the data. It is hypothesised that different types of metaphor are adopted to not only facilitate young children's understanding of particular scientific concepts (e.g. reproduction, sexual intercourse, fertilisation and so forth) but also to instil in them particular ideologies and moralities that are socio-culturally conditioned.

In what follows, the background of sex education in China is presented, followed by an overview of the theoretical approaches adopted in this study, i.e. Forceville's (1994, 1996, 2009) conception of pictorial and multimodal metaphors, and Morris's (1993) formulation of visual rhetorical processes. The metaphorical representations found in the data of the study are then presented, highlighting three types of metaphor, namely, personification, 
domestication and cross-experience metaphor. The three types of metaphor are then scrutinised in order to investigate the ways different types of metaphor function to address distinctive pedagogical and ideological agendas.

\section{SEX EDUCATION AND SEX EDUCATION MATERIALS IN CHINA}

Before sex education was brought to public attention in the mid-1980s (e.g. Pan, 1994; Liu, 2008), Chinese parents, when answering their child's question 'where did I come from?', would readily choose from a list of common answers shared by other parents:

1. You were picked up from the dumpsters;

2. You jumped out from the stone clefts;

3. You used to be a little monkey who lost its tail and became a little child. ${ }^{1}$

4. (a modern version) You were given as a free gift when dad and mum were charging our mobile phones. (Our translation)

Parents, who strive to ensure that they always impart the precise knowledge to their children, nevertheless fail on this particular topic, despite the fact they know the exact answer to this question. Long been considered as a taboo subject (or at least a private matter), the discourse of sex in China has always been confined to married couples within the privacy of their own homes. Not until the late 1980s, sex education was initiated to promote the sexual and reproductive health of teenagers (e.g. Aresu, 2009; Liu \& Su, 2014).

Needless to say, sex education for pre-school children is a rather challenging issue in terms of what to teach, how to teach, and why teach this topic. To start with, as childhood is often perceived as "a time of presumed sexual innocence with a belief that children do not or should not know anything about sexuality" (Stone, Ingham, \& Gibbins, 2013, p. 236), sex education is considered by some (e.g. Britzman, 1998) as being both unnecessary because (having) sex is inherently a human instinct that requires no teaching, and inappropriate 
because (having) sex is supposed to be an adult matter. Nevertheless, the last decade has witnessed a growing number of sex education picture books published and gaining popularity in Mainland China, in response to an increasing number of sexual offenses against young children.

For this study, seven sex education picture books (Text $1-7^{2}$ ) circulated in Mainland China $^{3}$ were collected, among which two were translated from Japanese (Texts 1 and 4), one from Korean (Text 3), and one from English (Text 6). In total, 139 multimodal image-text dyads (i.e. image and verbal text placed side by side; see Figures 2-4 for example) are featured in the seven texts. Some of the multimodal texts are non-metaphorical, such as the introduction of child birth which vividly shows a foetus emerging between a woman's legs (see Texts 1, 2, 4, 5, and 7). However, a significant number (48) of multimodal representations are metaphorical (see Table 1). In order to identify the nature of these metaphors, the next section adopts a cognitive approach to pictorial and multimodal metaphor (e.g. Forceville, 1996) and presents the verbal and visual representations of source and target domains of found in the seven sex education picture books.

\section{VERBAL, PICTORIAL, AND MULTIMODAL METAPHOR}

According to Forceville (e.g. 1994, 1996, 2009), metaphors fall into three categories, depending on the mode(s) employed: verbal, pictorial and multimodal metaphor. All three types of metaphor involve the association of two domains: namely, the source domain from which the metaphor draws and the target domain onto which the meaning is mapped. The source domain, referred to as the "vehicle" and the target domain, referred to as the "topic", are joined together by the "ground", which is the implied basis for the association of the two (e.g. MacKay, 1986; Bounegru \& Forceville, 2011). In other words, "topic" is understood in terms of "vehicle" on the basis of a certain "ground". 
Of the three types of metaphor, verbal metaphor associates the target and source domain via the figurative use of language. In the metaphor "TIME IS MONEY", the target and source domain are "time" and "money" respectively and the ground is the shared characteristics of being valuable. Pictorial metaphor, realised by non-verbal visual mode, involves the mapping of characteristics based on such similarities as "physical resemblance, spatial resemblance, resemblance pertaining to size and other properties" (Forceville, 1994, p. 3). For instance, in the pictorial metaphor verbalised "SHOE IS TIE", the advertised product shoe (the target domain) is associated with the ornamental item tie (the source domain) based on a "property transfer" of "nonfunctional beauty" (Forceville, 1994, p. 7). While both verbal and pictorial metaphor only involve one mode, multimodal metaphor involves a wider range of modes including gestures, sounds, music, smell, taste, touch and so on (Forceville, 2009, p. 23).

Following Forceville's categorisation of metaphors, an initial examination of the 139 image-text dyads in the seven sex education texts reveals 48 metaphorical representations (see Table $1^{4}$ ), ranging from verbal, pictorial and multimodal metaphors. For instance, in Text 1 , human reproductive organs are verbally metaphorised as "bags", hence a verbal metaphor; in Text 2, they are depicted with smiley faces, hence a pictorial metaphor; in Text 6 , they are referred to as "maps" by both the visual and the verbal mode, hence a multimodal metaphor. 
TABLE 1 Metaphorical representation in the seven sex education picture books

\begin{tabular}{|c|c|c|c|c|c|c|c|}
\hline & & \multicolumn{6}{|c|}{ Target domains } \\
\hline & & $\begin{array}{c}\text { Female reproductive } \\
\text { organs }\end{array}$ & $\begin{array}{c}\text { Male reproductive } \\
\text { organs }\end{array}$ & Sperm cells & Ovum & $\begin{array}{c}\text { Sexual } \\
\text { intercourse }\end{array}$ & Fertilisation \\
\hline \multirow{2}{*}{$\begin{array}{c}\text { Source } \\
\text { domains }\end{array}$} & Visual & $\begin{array}{l}\text { 1. A smiley face } \\
\text { 2. A smiley face } \\
\text { 3. Flower with a smiley } \\
\text { face; balloon full of } \\
\text { flowers } \\
\text { 5. A girly face } \\
\text { 6. Map }\end{array}$ & $\begin{array}{l}\text { 1. Face with eyes } \\
\text { and eyebrows } \\
\text { 5. Water pipe } \\
\text { 6. Map }\end{array}$ & $\begin{array}{l}\text { 2. A smiley face } \\
\text { 3. A group of boys and } \\
\text { girls } \\
\text { 5. Boy } \\
\text { 6. A sperm with a boyish } \\
\text { face } \\
\text { 7. Tadpole }\end{array}$ & $\begin{array}{l}\text { 2. A smiley face; } \\
\text { 5. Sugar drop } \\
\text { 7. Poached egg }\end{array}$ & $\begin{array}{l}\text { 3. Man kissing } \\
\text { woman } \\
\text { 5. Couple } \\
\text { exchanging } \\
\text { love }\end{array}$ & $\begin{array}{l}\text { 3. Running } \\
\text { competition } \\
\text { and a winner } \\
\text { sperm inside a } \\
\text { bubble full of } \\
\text { flowers; } \\
\text { 6. Swimming } \\
\text { competition }\end{array}$ \\
\hline & Verbal & $\begin{array}{l}\text { 1. Bag } \\
\text { 2. Place; route of } \\
\text { childbirth } \\
\text { 4. Bag } \\
\text { 5. Room; corridor; } \\
\text { 6. Map }\end{array}$ & $\begin{array}{l}\text { 1. Bag } \\
\text { 2. Place } \\
\text { 4. Bag } \\
\text { 5. Water pipe; bag } \\
\text { 6. Map }\end{array}$ & $\begin{array}{ll}\text { 1. } & \text { Source of life } \\
\text { 2. } & \text { Tadpole; seeds of love } \\
\text { 3. } & \text { Contestants } \\
\text { 4. } & \text { Source of life } \\
\text { 5. } & \text { Talking tadpoles; Boy } \\
\text { 6. } & \text { Students } \\
\text { 7. } & \text { Tadpole }\end{array}$ & $\begin{array}{ll}\text { 1. } & \text { Source of life } \\
\text { 4. } & \text { Source of life } \\
\text { 5. } & \text { Sugar drop } \\
\text { 6. } & \text { Competition } \\
\text { award } \\
\text { 7. } & \text { Poached egg }\end{array}$ & $\begin{array}{l}\text { 3. Fall in love } \\
\text { 4. Fall in love } \\
\text { 6. Intimately } \\
\text { being together }\end{array}$ & $\begin{array}{ll}\text { 3. } & \text { Running } \\
\text { competition } \\
\text { 5. } & \text { Swimming } \\
\text { competition } \\
\text { 6. } & \text { Swimming } \\
\text { competition }\end{array}$ \\
\hline
\end{tabular}

In order to characterise the functions of the verbal, pictorial and multimodal metaphors found in the seven sex education texts, this paper draws upon and extends Morris's (1993) "processes of visual rhetoric" to investigate how metaphors differ from each other in terms of their particular meaning-making processes. In doing so, this study provides an account of the different types of verbal, pictorial and multimodal metaphors which are categorised in relation to the rhetorical processes which are involved, based on Morris (1993).

\section{METAPHORS AS RHETORICAL PROCESSES}

In the analysis of political cartoons, Morris (1993) proposes four types of visual rhetorical processes governing the association between the target and source domain: condensation, combination, opposition, and domestication. The process of condensation involves the "compression of a complex phenomenon into a single image that is purported to capture its essence graphically" (Morris, 1993, p. 200). For example, the multifaceted issue of inflation is condensed into an enormous and ferocious monster towering over the government leader. 
Combination, which blends "elements and ideas from different domains into a new composite that remains clearly identifiable as something that contains each of its constituents" (Morris, 1993, p. 200), may be found in the graft of a politician's head onto the body of an animal. The process of opposition, which is based on de Saussure's and others' work (e.g. de Saussure, 1966), construes reality in terms of gender opposition. For example, the use of male and female opposition can be used to represent the French and English language in Canada. The process of domestication, drawn from Goffman (1979), refers to the use of the familiar to represent the distant and less familiar. For instance, prior to the US war against Iraq, the still unknown Saddam Hussein was depicted as the image of a new Hitler, thereby justifying the American military act. Since visual rhetorical processes (i.e. condensation, combination, opposition and domestication) account for the very mechanisms of meaning making by metaphorical representations, they will be adopted to explain the different types of metaphors utilised in the sex education texts.

While Morris's notion of rhetorical process is based on the visual mode only (hence the "visual rhetoric"), it is extended by the present study to the analysis of verbal metaphors and multimodal metaphors as well so as to investigate their particular meaning making functions. Following this concept, three types of metaphorical representations are identified in Table 1.

(a) Personification metaphor: This involves the transference of human characteristics onto inert reproductive organs, sperm cells and ovum. For example, in Texts 1-3, a smiley face is grafted onto female reproductive organs, and elsewhere in Text 3, sperm cells are depicted with human heads to represent boys and girls. While the rhetorical process of personification metaphor resembles that of combination metaphor (or can be perceived as a subcategory of combination metaphor), it is specifically termed as such to refer to the particular representation of human beings as the source domain in children's texts. 
(b) Domestication metaphor: This type of metaphor, proposed by Morris (1993), refers to the use of commonplace, everyday objects and events to represent the biological entities and processes based on their similarities of one kind or another. For example, human reproductive organs are represented by the objects of bag, water pipe, map, and so forth and human fertilisation is represented in Texts 3-6 as "competition". In this study, domestication metaphors are of particular interest in terms of the selection of source domains and the implied basis for the association for the purpose of investigating the particular socio-cultural values and ideologies reflected in sex education books in Mainland China.

(c) Cross-experience metaphor: In representing the physiological activity of sexual intercourse, a unique type of metaphor is identified that uses the psychological state of "being in love" as the source domain. This metaphor, in line with the cognitive concept of “embodiment" (e.g. Johnson, 1987), focuses on the particular aspect of mind-body crosscoupling where the mind is used as the "vehicle" to represent the topic of bodily experiences. In the present study, this type of metaphor is termed "cross-experience metaphor" to highlight the relation between mind and body in construing social realities. In this study, crossexperience metaphors are examined in order to shed light on how the socio-culturally sensitive topic of sexual intercourse is construed to both cater to the unique readership and conform to socially-conditioned values and moralities governing sex education in Mainland China.

To summarise, Figure 1 shows the features of source and target domains of the three types of metaphors found in the data. 


$\begin{array}{lcll} & \text { source domain } & & \text { target domain } \\ \text { personification metaphors } & \text { human } & & \\ \text { domestication metaphors } & \text { familiar, concrete } & \longrightarrow & \text { non less familiar, abstract } \\ \text { cross-experience metaphors }\left\{\begin{array}{lll}\text { mind } \\ \text { body }\end{array}\right. & \longrightarrow \text { body }\end{array}$

FIGURE 1 Target and source domains in three types of metaphors

In the following sections, each of the three types of metaphor is illustrated, focusing on the selection of source domains as well as the association basis that is both pedagogically and ideologically significant.

\section{Personification Metaphors: Construing the Differences of Sex and Gender}

Drawing from the "richest domain of knowledge" about human beings and animals, personification metaphors serve to "generate an educated guess about less familiar, nonhuman objects" (Inagaki \& Hatano, 1987, p. 1020). Components of personification metaphors include: "topic (the animal or being commented on), vehicle (the human characteristics attributed to the topic), and ground (the implied basis for assigning the vehicle to the topic)" (MacKay, 1986, p. 88). As can be seen in Table 1, the "topics or target domains of personification metaphors include female and male reproductive organs, sperm cells, and ovum, all of which are consistently grafted with either male or female faces. In this way, the target domains are construed as though they were conscious beings possessing a designated sex. The ground, or the projected human characteristics, is rather salient in that it construes 
not only the differences of sex (i.e. male and female) but also that of gender (i.e. masculinity and femininity).

Figures 2(a) and (b) in Table 2 are taken from Text 5, where the narrative thematises the growth of a young boy called Duoduo and a young girl called Xiaomi. Figure 2(a) personifies the sperm cell as a boy while Figure 2(b) personifies female reproductive organ as a girl. The visual and verbal cuing of their target and source domains is presented in Table 2. In Figure 2(a), the personification metaphor, verbalised as "SPERM CELL IS BOY", has both its target and source domain multimodally cued. Firstly, the target domain sperm cell is visually represented by the magnified sperm cells as though they were observed under the microscope. A verbal label "Sperm cell” in both Chinese characters (“精子”) and Pinyin ("Jingzi") is linked with one of the magnified sperm cells by dotted lines, specifying its technical name. The source domain boy is visually cued by the image of a sperm-shaped creature with a boyish face and in the typical attire for boys: a stripy shirt and a hat.

TABLE 2 Personification of sperm cell and female reproductive organ

\begin{tabular}{|c|c|c|c|c|}
\hline & & & Visual & Verbal \\
\hline \multirow{2}{*}{$\begin{array}{l}\text { Figure } \\
\text { 2(a) }\end{array}$} & $=18$ & $\begin{array}{l}\text { Target: } \\
\text { Sperm cell }\end{array}$ & $\begin{array}{l}\text { Magnified sperm cells as though they } \\
\text { were viewed under microscope }\end{array}$ & $\begin{array}{l}\text { Verbal tag that reads "Sperm cell" } \\
\text { in both Chinese characters and } \\
\text { Pinyin }\end{array}$ \\
\hline & $\left(\begin{array}{c}1 \\
n+m\end{array}\right.$ & $\begin{array}{l}\text { Source: } \\
\text { Boy }\end{array}$ & $\begin{array}{l}\text { A sperm cell with a boyish face and } \\
\text { wearing a hat askew and a stripy shirt }\end{array}$ & $\begin{array}{l}\text { Boy represented as the "sayer" in } \\
\text { the verbal process }\end{array}$ \\
\hline \multirow{2}{*}{$\begin{array}{l}\text { Figure } \\
\text { 2(b) }\end{array}$} & 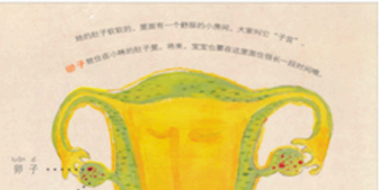 & $\begin{array}{l}\text { Target: } \\
\text { Female } \\
\text { reproductive } \\
\text { organ }\end{array}$ & Female reproductive organ & $\begin{array}{l}\text { Verbal tag that reads "Uterus" in } \\
\text { both Chinese character and Pinyin }\end{array}$ \\
\hline & 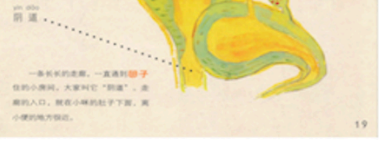 & $\begin{array}{l}\text { Source: } \\
\text { Girl }\end{array}$ & $\begin{array}{l}\text { Female reproductive organ with a } \\
\text { female face }\end{array}$ & Nil \\
\hline
\end{tabular}


In the verbal mode, the text in the speech balloon has sperm cells as the "sayer" initiating a verbal process (cf. Halliday, 2014):

Original text in Chinese:

小精子们七嘴八舌地嚷嚷说: “我们想要长大, 我们想要变成小宝宝！”

\section{Literal translation:}

The little sperm cells are clamouring all at once: "We want to grow up, (and) we want to become little babies!"

In this verbal metaphor, sperm cells are depicted as though they were capable of talking. The verb "clamour" and the adverbial phrase "all at once" map the characteristics of being noisy and energetic onto the sperm cells. While there is no clear indication of male or female for the sperm cells, the characteristics of being boisterous and clamorous tend to associate more with young boys, therefore complementing the image of the male.

Comparatively, the sex of female is also mapped onto female reproductive organ featured in Figure 2(b). The female reproductive organs in the image includes uterus, fallopian tubes, ovaries, ova, and vagina, each also labelled with technical names in both Chinese characters and Pinyin. The source domain is visually cued by the image of a girl with pigtails (represented by the shape of fallopian tubes, uterus, and vagina). A female face is depicted in the uterus area, with her eyes and lips closed, suggesting a sense of shyness, calm, and timidity.

Including the multimodal metaphors in Figures 2(a) and (b), 14 personification metaphors are found in the data that consistently assign corresponding sexes to male and human reproductive system. That is, male reproductive organs and sperm cells tend to be depicted with the sex of male while the female reproductive organs tend to be depicted with that of female. 
The construal of sex differences frequently featured in the personification metaphors may be partly due to pedagogical concerns. As it is relatively challenging for pre-school children to understand the formation of sex as the combination of $\mathrm{x}$ - and $\mathrm{y}$ - chromosomes, representing human reproductive organs with corresponding sexes makes it more accessible for young readers to arrive at a concrete, though not entirely precise, understanding of sex differences. However, personification metaphors as such also construe, either explicitly or implicitly, gender stereotypes that associate the sex of male with masculinity and that of female with femininity. For example, explicit representations can be found in Figures 2 (a) and 2(b) in Table 2 where the male identity is associated with the characteristics of being clamorous and energetic while the female is portrayed as being bashful and reticent. Implicit representations of gender stereotypes, on the other hand, are featured exclusively in the roles of sperm cells and ovum in the process of human reproduction.

In Texts 3, 5 and 6, sperm cells are unanimously metaphorised as the contestants in the "competition" of fertilisation (a domestication metaphor; see more detailed discussion in the next section). The ovum, if represented, is construed as the trophy for the winning sperm. In all three texts, sperm cells are personified with an enterprising spirit in the tough yet rewarding process of fertilisation. In Text 3, the sperm cell that wins the "swimming competition" of fertilisation is visually depicted with a crown and as cheering with pride inside the uterus . In Text 5, sperm cells experience the perilous journey through the maze of the vagina where some "get lost", some "become too exhausted to swim", and the not so strong ones even "die along the journey". When the "healthiest, strongest, and smartest little sperm cell" reaches the finish line - the ovum, it "faces its head against the ovum" and "forcefully pushes into it". In Text 6 , the sperm cell named Xiaowei ${ }^{6}$, an excellent swimmer, wins the race against 300 million other sperm cells. As he approaches the "lovely" and "soft" ovum, he unites with it and disappears, hence suggesting the fusion of the two. 
In all three cases, the personification of sperm cells makes them the "actor" (the entity which acts), while depicting the ovum as the "goal" (the entity which is impacted) in the process of fertilisation (e.g. Halliday, 2014). In this actor-goal representation, sperm cells are bestowed with the qualities of being active, motivated, and energetic, while the ovum is represented as an immobile object, passive yet attractive, waiting to be conquered by the most outstanding sperm cell. The opposing roles of sperm cells and ovum echo Martin's (1991) analysis of the gendered representation in science texts:

It is remarkable how "femininely" the egg behaves and how "masculinely" the sperm.

The egg is seen as large and passive. It does not move or journey, but passively "is transported", "is swept", or even "drifts" along the fallopian tube. In utter contrast, sperm are small, "streamlined", and invariably active. They "deliver" their genes to the egg, "activate the developmental program of the egg", and have a "velocity" that is often remarked upon. Their tails are "strong" and efficiently powered. (Martin, 1991, p. 489; emphasis in original)

The personification metaphors used to represent the role of sperm cells in the process of fertilisation fits what is known as a "sperm saga" (The Biology and Gender Study Group, 1988) where the sperm cell is depicted as the "heroic victor" and the ovum as the prize awarded to the victorious sperm. This representation of the ovum also echoes Schatten \& Schatten's (1984) findings where the ovum is compared to the Sleeping Beauty and awaits the magic kiss and penetration of the active and masculine sperm cell. It is through the cognitive analysis of metaphors that the "sleeping metaphors" with regard to gender stereotypes in sex education are awakened so as to "rob them [metaphors] of their power to naturalise our social conventions about gender" (Martin, 1991, p. 501).

\section{Domestication Metaphors: Familiarising the Abstract Concepts}

Associating the more familiar and concrete objects and events with the less known and 
abstract ones, domestication metaphors are predominately used in sex education texts to familiarise such biological knowledge as human reproductive organs, sperm cells, ovum, and fertilisation, all of which are well beyond the here-and-now experiences of pre-school children. Unlike personification metaphors, the source domains of domestication metaphors are more diversified. For example, containers such as bag (Texts 1, 4, and 5) and balloon (Text 3) as well as architecture (Texts 2 and 5) are used exclusively to represent human reproductive organs. Symbolic objects such as "sources of life" are adopted to represent sperm cells and ovum (Text 2). Edible items are used in Text 5 (sugar drop) and 7 (poached egg) to metaphorise the ovum. In domestication metaphors, the topic is the less familiar, abstract object or event metaphorised, and the vehicle is the more familiar, concrete object or event. In the seven sex education texts, the domestication metaphors employed are presented in Table 3 in terms of topic, vehicle and ground. 
TABLE 3 Topic, vehicle and ground of domestication metaphors in the data

\begin{tabular}{|c|c|c|}
\hline Topic & Ground & Vehicle \\
\hline \multirow{3}{*}{ Human reproductive organ } & Resemblances in functionality & Container \\
\hline & $\begin{array}{l}\text { Resemblances in functionality \& cultural } \\
\text { connotations }\end{array}$ & Architecture \\
\hline & Cultural connotations & Map \\
\hline Male reproductive organ & Resemblances in shape and functionality & Water pipe \\
\hline \multirow{2}{*}{ Sperm cell } & $\begin{array}{l}\text { Resemblances in shape and evolution } \\
\text { \& cultural connotations }\end{array}$ & Tadpole \\
\hline & $\begin{array}{l}\text { Resemblances in functionality } \\
\qquad \& \text { cultural connotations }\end{array}$ & $\begin{array}{l}\text { Source of life; } \\
\text { Seed of love }\end{array}$ \\
\hline \multirow{2}{*}{ Ovum } & $\begin{array}{l}\text { Resemblances in functionality } \\
\text { \& cultural connotations }\end{array}$ & Source of life \\
\hline & $\begin{array}{l}\text { Resemblances pertaining to other properties (e.g. } \\
\text { the "attractiveness" of ovum to sperm cells) }\end{array}$ & Edible item \\
\hline Fertilisation & Resemblance in form \& cultural connotations & Competition \\
\hline Foetus & Resemblances in shape \& cultural connotations & $\begin{array}{l}\text { Fish and } \\
\text { monkey }\end{array}$ \\
\hline
\end{tabular}

As can be seen in Table 3, the ground of domestication metaphors generally falls into two categories: resemblances (in terms of functionality, shape, evolution) and cultural 
connotations (the socio-culturally contextualised symbolic relations between the topic and the vehicle). The association based on resemblances is fairly straightforward. For instance, in the following example from Text 4 , the resemblance of functionality is the basis for assigning the source domain of bag to the target domains of female ovaries and male testicles:

Original text in Chinese:

妈妈的肚子里有两个叫做“卵巢”的袋子; 爸爸的两腿之间也有两个袋子，叫做“睪丸”。

Literal translation in English:

In mum's tommy, there are two bags called “ovaries”; between Daddy's legs, there are also two bags, which are called "testicles".

In this example, two "bag" metaphors are structured in an identical manner (i.e. "OVARIES ARE BAGS" and "TESTICLES ARE BAGS”), prioritising the resemblances among ovaries, testicles, and bags in their function of being containers of items while deemphasising other physical properties such as their internal structure, material composition, etc. The items contained in the "bags" of ovaries and testicles are ova and sperm cells respectively, both of which are metaphorised as "sources of life", indicating their roles in the formation of life. Here, the association between the topic of sperm cells and ova with the vehicle of "sources of life" is one that is governed by particular social stances and perceptions, i.e. one that follows modern reproductive biology. Another similar example can also be found in the metaphorisation of sperm cells as the "seeds of love". In this metaphor, the conception of life is metaphorised as the growth of plants, with sperm cells as the symbolic "seeds" and the modifier "love" highlighting the centrality of positive affections in sex education. The theme of love, which runs through the education about sex and sexuality in the data, will be further elaborated in the following section in the discussion crossexperience metaphor. 
In another case where resemblance in functionality configures with cultural connotations, human reproductive organs are represented using architecture metaphors, such as "place" and "room" for ovaries and "route of childbirth" and "corridor" for vagina and so on. In Text 5, for example, the female uterus is metaphorised as "room":

Original text in Chinese:

她的肚子软软的, 里面有一个舒服的小房间, 大家叫它“子宫”。卵子就住在小咪的肚子

里。将来, 宝宝也要在这里面住很长一段时间哦。

\section{Literal translation in English:}

Her tummy is soft. There is a cosy little room inside, (and) people call it "uterus". Ova live inside Xiaomi's tummy. In the future, a baby will also live here for quite a while.

Apart from being a physical habitat, the vehicle of "room" also bears such cultural connotations as the feelings of security, relaxation and comfort, echoing the modifiers "cosy" and "little" in the above example. The growth of foetus inside the female uterus is projected with affections and sentiments that young children could associate with not only the security of being at home but also the warmth and peace of their mothers' embrace. Moreover, instead of giving answers like "you jumped out from the stone clefts", the way how human conception is introduced in this text draws from something more familiar and mentally close to young children and the established sympathy contributes to the understanding of abstract biological knowledge by young children.

In Texts 2, 5, and 7, the vehicle of tadpoles is used to represent sperm cells based on resemblance in shape and evolution as well as cultural connotations. First of all, tadpoles and sperm cells (viewed under a microscope) bear striking physical resemblance in both featuring a disproportionately large head and long tail. Furthermore, the maturation of tadpoles into frogs also resembles the growth of human foetus whose body and limbs are gradually formed in the process of conception. From the cultural perspective, the association of tadpoles and 
sperm cells is attributed to a well-known Chinese nursery tale entitled "Little Tadpoles Looking for Mama” (小蝌蚪找妈妈; Xiaokedou zhao mama), which depicts an adventurous journey of little tadpoles in search of their mother. After misrecognising duck, goldfish, crab, and turtle as their mother (all of which share certain physical similarities with them), the little tadpoles finally find their real mother - the frog. Similar to tadpoles' journey to find their mother, sperm cells, likewise, are also on the toilsome expedition to unite with the ovum (i.e. the metaphorisation of fertilisation as "competition"). Therefore, sperm cells and tadpoles not only share similar physical characteristics but also strive to fulfil similar missions. Also employing familiar animals as the source domains is the use of fish and monkey to metaphorise the shape of the foetus at different growth stages. With pre-school children relatively more familiar with animals such as tadpoles, fish, and monkey, these domestication metaphors would no doubt facilitate their understanding of the more technical knowledge regarding human reproduction.

In Text 6, one metaphorical representation stands out - the "map" representations for human reproductive organs featured. The two images in Figure 3 feature a sectional view of the human abdomen and respectively show male genital organs (on the left image) and female vagina (on the right image). The two drawings, indicated by the verbal tags as the "body map" for Mr and Mrs Brown, resemble treasure-hunting maps. Apart from the indication of directions by arrow symbols and two compass roses (one in each map), it also includes verbal tags to mark the starting point, advancing direction, entry point, specific locale, and the finishing point. The clear marking of directions for the sperm cells to reach the ovum echoes Lupton's (2003, p. 157) findings where the directions are given by the hypothalamus to the pituitary gland and communications take place between the hormones and tissues/ organs. According to the narrative in Text 6 where the "map" metaphor is from, the instruction given to the sperm cells is "given" by their "teacher" which metaphorises the 
physiological act of male ejaculation. In this case, the domestication metaphor (i.e. the "map" metaphor) works synergistically with the personification metaphor (i.e. sperm cells as "students") to mitigate the straightforwardness of the scientific account and construe the culturally sensitive matter of sexual intercourse and ejaculation in a way that is both more familiar and more age-appropriate for young children.
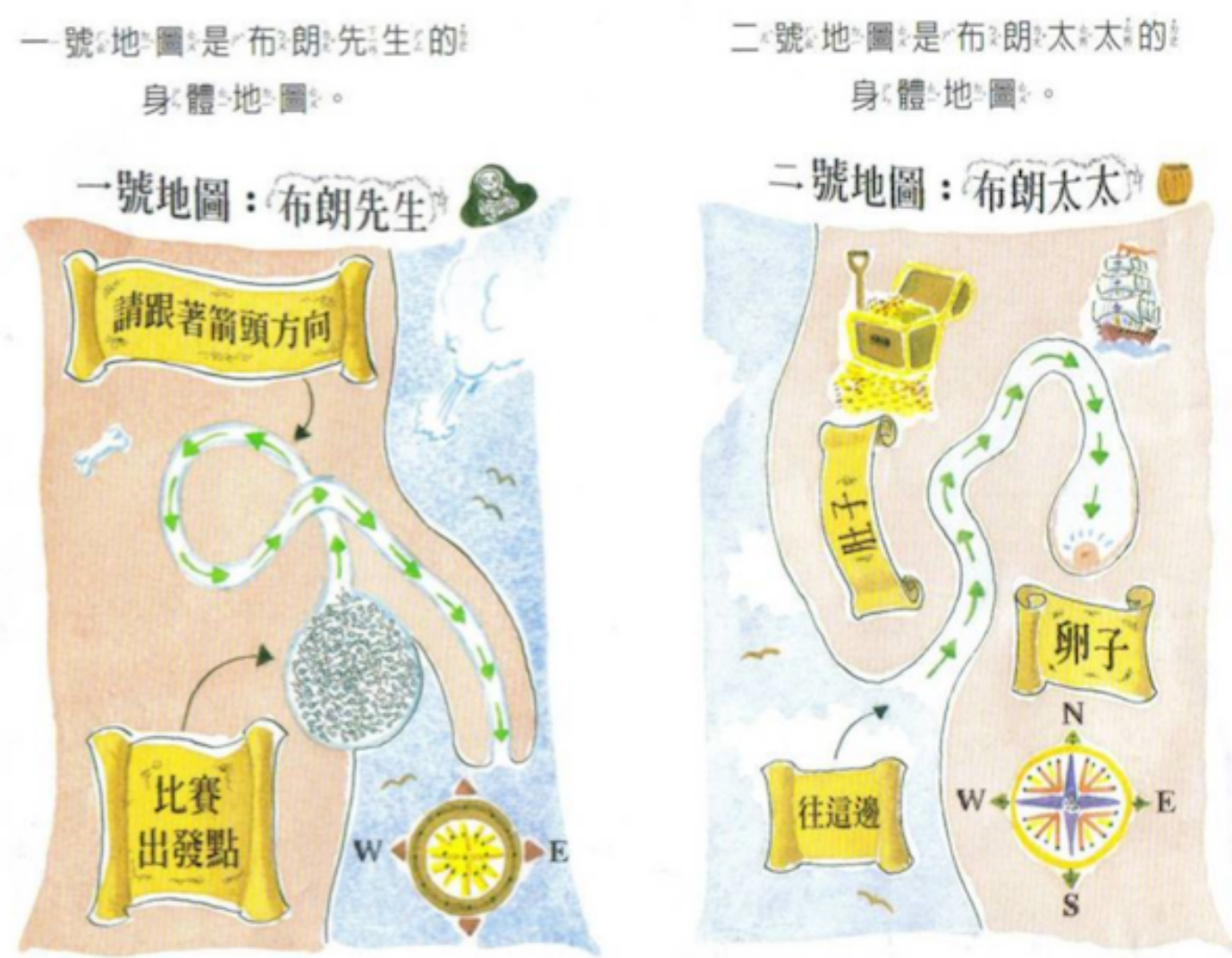

FIGURE 3 Map metaphor for human reproductive organs

Another prominent feature in the map metaphor is the construal of the ovum as something valuable. On the map representing female reproductive organs, a treasure chest is shown halfway through the advancing route, with the lid open and gold scattered all over the ground. This representation is likely to suggest that more precious treasures are to be found later. At the finishing point, the ovum is depicted verbal-pictorially (with the name shown in 
a scroll) and also visually, showing the ovum as though it were glowing, like the ultimate treasure. Just as Martin (1991, p. 486) finds with regard to the scientific explanations of human reproduction, "at a fundamental level, all major scientific textbooks depict male and female reproductive organs as systems for the production of valuable substances, such as eggs and sperm". The value and allure of the ovum is not incidental across the data. In Text 5, the ovum is represented as a sugar drop, an edible item that often appeals to young children. In Text 7, the ovum is depicted as a poached egg, echoing the Biology and Gender Study Group's (1988, p. 63) findings in a few biological textbooks where "the yolk-laden egg was seen as being pursued by hungry sperm seeking their nourishment".

In domestication metaphors, existing knowledge about the more familiar and concrete source domains is drawn upon for the understanding of novel ideas and phenomena (e.g. Vosniadou, 1987). Therefore, metaphors as such are widely used in teaching scientific knowledge (e.g. Aubusson, Harrison \& Ritchie, 2006; Cameron, 2003). Apart from the pedagogical concerns, as the analysis shows, the particular selection of vehicles and the characteristics mapped onto the topics are also ideologically significant. For example, the metaphorisation of female uterus as "room" arouses the affections of security and warmth and in a sense, serves to "bridge the gap between the cognitive and affective domains" for young children (Duit, 1991, p. 653). Therefore, domestication metaphors do not only serve to facilitate the pedagogical purpose of acquiring biological knowledge, but also draw attention to particular socio-cultural ideologies, which are further reinforced in the representation of the essential, yet sensitive, topic of sexual intercourse through the use of cross-experience metaphors which is discussed in the next section. 


\section{Cross-experience Metaphors: Representing the Mind-Body Connection}

One of the fundamental principles governing the cognitive studies of metaphor is the crosscoupling between body and mind. In suggesting ways of "putting the body back into mind", Johnson (1987, p. xxxviii) highlights the interrelation between the "consciousness and rationality" and the "bodily orientations and interactions in and with our environment". The conceptual metaphor "MIND IS BODY" is founded on the very aspect of mind-body association that is known as "embodiment" (e.g. Johnson, 1987; Lakoff \& Johnson, 1999). Embodiment features "our innate capacity to imaginatively project from certain wellstructured aspects of bodily and interactional experience to abstract conceptual structures" (Lakoff, 1988, p. 121). As Gibbs (2006, p. 9) points out, "understanding the embodied nature of human cognition demands that researchers specifically look for possible mind-body and language-body connections". While the "MIND IS BODY" metaphor is based on the particular aspect of mind-body connection that attributes the understanding of the cognitive to that of the physical, in the particular genre of sex education texts, a complementary aspect of the mind-body association is found that features the understanding of the body based on that of the mind, i.e. "BODY IS MIND". In order to highlight both aspects of the mind-body connection, the term "cross-experience metaphor" is thus coined by the present study to refer to both the interpretation of mind based on that of body and vice versa. In sex education texts, the relation between mind and body mainly features the "BODY IS MIND" representation, integrating the introduction of biological knowledge about the human body with that of mental feelings and moral values. In Texts 3, 4, 5, and 6, the cross-experience metaphor of "BODY IS MIND" features exclusively the sensitive topic of sexual intercourse and is specifically manifested as the general metaphor of "SEXUAL INTERCOURSE IS MAKING LOVE”. 
Interestingly, this might not be regarded as a metaphor at first glance, simply because the term "making love" is so frequently used as the euphemistic reference of "sexual intercourse" that the metaphorical association tends to be downplayed. In this metaphor, the psychological experience of "making love" is used as the source domain to represent the bodily experience of sexual intercourse. The physiological engagement of human bodies is understood as the mental state that features the feeling of love. The association between sexual intercourse and the "making" of love is deeply rooted in socio-cultural perceptions where sex often entails the affections of "intimacy and care" (Berlant \& Warner, 1998, p. 557) and the failure to distinguish the two is partly due to the common usage of "making love" to refer to sexual intercourse (Jankowiak \& Fischer, 1992).

In Texts 3 and 4, sexual intercourse is verbalised as the moment when mother and father are "falling in love". Known as the "container metaphor" previously discussed by cognitive linguists (e.g. Lakoff \& Johnson, 1980), the mental state of falling in love is used to represent the physical activity of sexual intercourse, thus also forming a cross-experience metaphor. Similarly in Text 6, sexual intercourse is verbally referred to as mother and father "intimately being together". The expression "intimately" suggests both the physical and mental distance between the couple. When referring to the mental distance, it also forms a cross-experience metaphor that involves the construal of the physiological experience of sexual intercourse by way of the affective experience of intimacy. 


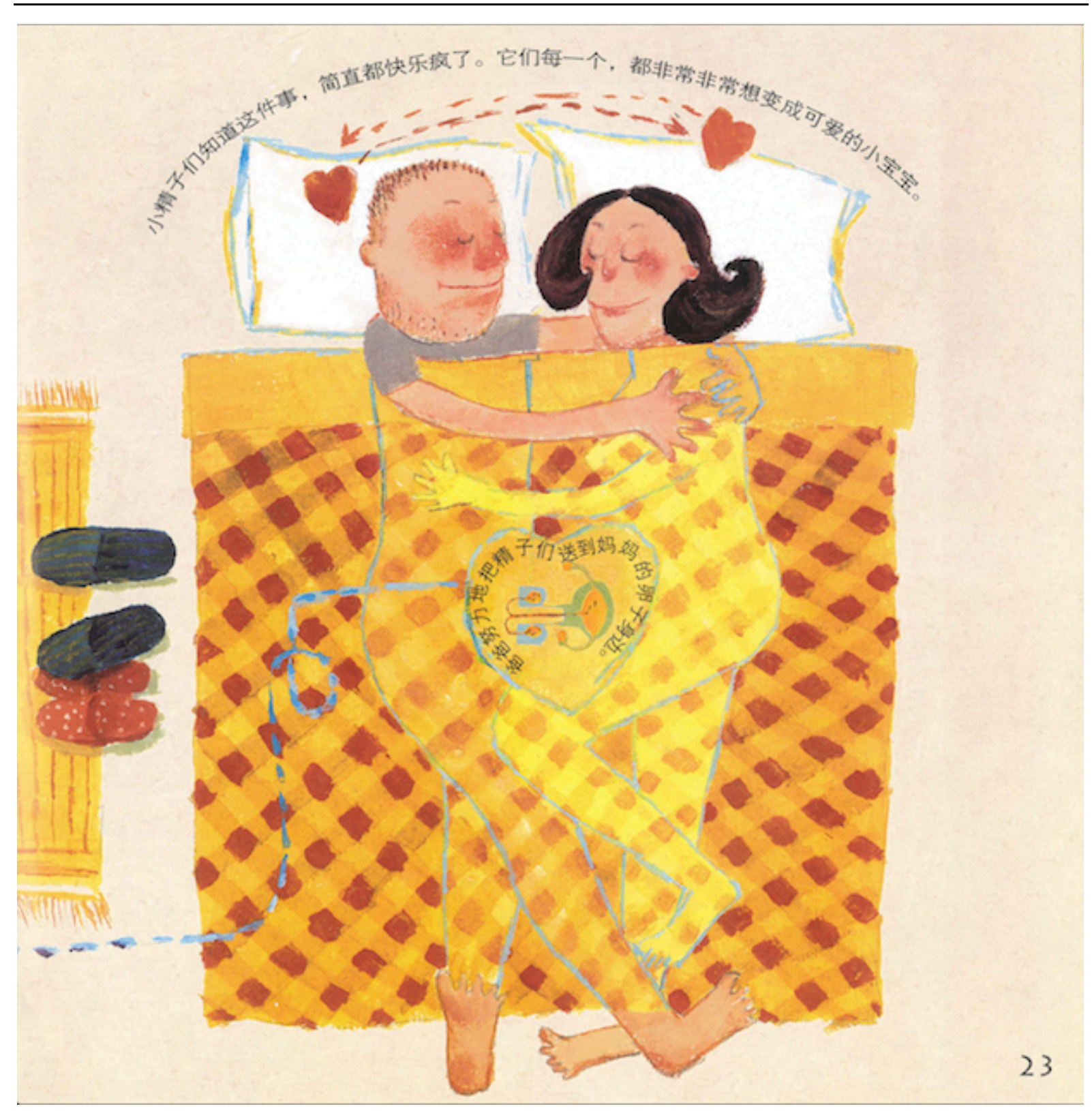

FIGURE 4 A cross-experience metaphor for sexual intercourse in Text 5

In Figure 4, verbal and visual elements collaboratively represent the bodily experience of sexual intercourse as "making love". In this figure, a man and a woman are shown lying in bed, embracing. Their eyes are closed, as though they were asleep. Two red heart symbols connected by arrows are placed above their heads. A heart-shaped text balloon is placed in their abdominal area and shows the linking of the male and female reproductive organs, euphemistically indicating the act of sexual intercourse. The text reads: 
Original text in Chinese:

爸爸努力地把精子们送到妈妈的卵子身边。

Literal translation in English:

Dad tries his best to send the sperm cells to mum's ovum.

The verbal account represents sexual intercourse as an active process, complementing the visual depiction of sexual intercourse that shows the male and female reproductive organs joining inside the heart-shaped balloon. The repeated use of heart shapes in the visual mode is associated with particular meanings in Chinese culture. For example, in traditional Chinese medicine, the inner organ of heart is considered to be the "master" or "ruler" of the body, the "locus of intellectual activity" and the "locus of emotional activity" (Yu, 2008, p. 139). As the "master" of human body, the organ of heart exercises authority over the other body parts and governs the activities they are engaged in. As the "locus of intellectual activity", it is considered to be the "central faculty of cognition" (Yu, 2008, p. 132). As the "locus of emotional activity", it is also directly related with the feeling of joy (Yu, 2008, p. 138). Meanwhile, heart symbols have also been used as popular cultural icons to represent the affection of love (e.g. the use of "heart" as Predicator in the expression: "I heart you".). Meanings of heart shapes featured in the visual mode in Figure 4 are thus multifaceted: the couple are joyfully exchanging the feeling of romantic love; the activity they are engaged in is governed by their heart. The activity, which is the physiological act of sexual intercourse, is euphemistically indicated by the verbal and visual elements inside the heart-shaped text balloon placed in the couple's abdominal area.

The "intrinsic relationship" between the abdominal area and sexual intercourse suggests an association of sexual unity with emotional unity (Urios-Aparisi, 2010, p. 192). Whereas in Urios-Aparisi's (2010) analysis of films, the construction of "love unity" highlights the "pleasure of physical union" as the "utmost pleasure and harmony" (Urios-Aparisi, 2010, p. 
198), by situating the introduction of sexual intercourse within family settings, sex education texts for young children emphasise conjugal love as the motivating factor to sexual intercourse (Liang et al., 2016). This fits with the Confucianism attitudes on sexuality that associate sexual intercourse with procreation, that prohibit pre-marital sex, and that require the spiritual (rather than carnal) expression of sex (Pan, 1994). While the relationships among marriage, love, and sex have significantly transformed in Mainland China since the 1980s (e.g. Pan, 1994; Higgins, et al., 2002), a traditional view on sexuality is still conveyed to young children in the analysed sex education books, promoting the view that sexual intercourse is all about conjugal love and sex is directly related with procreation. This view also echoes with the previously discussed domestication metaphor that represents the sperm cells as the "seeds of love" and "sources of life" (see Table 3), all of which reflect the stances and efforts of sex education in Mainland China to promote traditional (and relatively more conservative) views on sexuality.

The particular values and moralities conveyed in sex education books for Chinese young children also support the view that "sex education is inevitably emotional work" (Sandlos, 2010, p. 299). Sex education texts are not merely intended to facilitate the introduction of sex-related knowledge, but also serve as "an emotional signifier of hopes, worries, uncertainties, life chances, and relations with others" (Sandlos, 2010, p. 302). In the seven sex education texts, the way how sexual intercourse is construed significantly reflects the stances, concerns, focus, and ideologies of sex education for pre-school young children in China. The texts as such are gradually gaining popularity in China not only due to their particular moralities and concerns that conform to mainstream Chinese family values, but also because of the nature of knowledge that is "positively enriching and that enhance personality, communication and love" (WHO Technical Report Series No. 572). In the data, the use of cross-experience metaphors that highlight a "BODY IS MIND" metaphor is thus 
conducive to the delivery of sex knowledge in China that both conforms to traditional moral and ethical requirements and contributes to the sound physical and mental growth of young children.

\section{CONCLUSION}

The use of personification, domestication, and cross-experience metaphors in the seven sex education picture books corresponds respectively to the following dualisms that are both pedagogically and ideologically laden: male/masculine and female/feminine, scientific and mundane, mind and body. The analysis has confirmed the hypothesis set out at the outset of the paper; namely that different metaphors have different pedagogical and ideological functions and meanings, as discussed below.

Firstly, through the use of personification metaphors, gender ideologies "creep unnoticed" into the account of science (Martin, 2001, p. 4). Human reproductive organs are construed to differ not only between the male and the female but also between the masculine and the feminine. For example, in introducing the process of fertilisation, sperm cells, personified as boys, play the active role, while the ovum, which tends not to get personified, is often depicted as being inert and passive. In other words, "the determination of maleness and femaleness has also been inscribed by concepts of active masculinity and passive femaleness" (The Biology and Gender Study Group, 1988, pp. 66-67). Therefore, the biological formation of sex difference is also socially constructed and highlights the gender stereotypes that associate male with masculinity and female with femininity. The integration of sex differences with gender differences confirms the feminist critique towards certain biological books (sex education books included) in their implicit construction of gender stereotypes which are acquired and then naturalised in young children. 
Secondly, the dualism between scientific and mundane is featured in domestication metaphors that facilitate the understanding of biological knowledge through the use of commonplace objects and events. The metaphorical process involves the mapping of characteristics in terms of resemblances of one kind or another and/or cultural connotations. For instance, due to their resemblances in functionality, human reproductive organs are metaphorically represented as containers; due to their resemblance in shape and their associations in Chinese culture, sperm cells are metaphorised as tadpoles. Through domestication metaphors, what is biological is construed as commonplace so that young children could rely on their everyday knowledge to understand the distant and abstract knowledge. Furthermore, the selection of source domains is also socio-culturally significant in terms of the characteristics that get projected onto the source domains. For example, the ovum is metaphorised as a valuable item in order to highlight the sanctity of sex and the preciousness of life. Therefore, domestication metaphors are also ideologically meaningful in categorising social realities and prioritising what is regarded as critical and significant.

Thirdly, cross-experience metaphors are employed that highlight the dualism of mind and body. In sex education texts, the cross-coupling between mind and body is embedded in the introduction of the essential yet sensitive a topic of sexual intercourse. Through the use of cross-experience metaphors, the bodily experience of sexual intercourse is construed as the psychological state of "falling in love" or the experience of both physically and mentally "intimately being together". With the vehicle of "making love" in the domain of mind used to metaphorise the topic of sexual intercourse in the domain of body, the affection of conjugal love is foregrounded and prioritised as the driving force of the physiological behaviour of sexual intercourse.

Through the use of personification, domestication and cross-experience metaphors in sex education texts, young children's cognitive processes are facilitated to better understand 
scientific knowledge about sex and sexuality. Meanwhile, ideologies with regard to gender stereotypes and mainstream values on sex and sexuality are also implicitly construed. By applying a cognitive approach to metaphor to examine the relation between the target and source domain, this study has highlighted pedagogical and ideological concerns, and awakened "sleeping metaphors" (Martin, 1991), so as to bring to light the socio-cultural values that are projected onto the construal of sex-related knowledge for young children in Chinese society.

\section{ACKNOWLEDGEMENT}

This work is supported by the Project of Humanities and Social Sciences, Ministry of Education, People's Republic of China [Grant No. 14YJC740047].

\section{NOTES}

1. Answers 2 and 3 are based on the character of Monkey (Sun Wukong) from Journey to the West (Xiyouji), a classic novel in ancient China and yet still many children's favourite nowadays.

2. Texts 1 to 7 are: 1): "Story of the Pee-pee"; 2): "Dad and Mum, How was I Born?"; 3): “How was I Born?”; 4): “My Story: Boys"; 5): "How did Mum and Dad Have Me?”; 6): “Where Willy Went”; 7): “Where did I Come from?”.

3. Text 7 is published by in Hong Kong by the Family Planning Association of Hong Kong and can be purchased from the following website: http://www.famplan.org.hk/sexedu/B5/resource/Resource_details.asp?reID=5. All the other six books are easily accessible in Mainland China. 
4. The Arabic number preceding each source domain indicates the text in which the metaphor is found. For example, the entry "6. Map" in the row "visual" and the column "female reproductive organs" means that in Text 6 , female reproductive organs as the target domain are visually represented as a map. The entry "2. Place; Route of childbirth" means that female reproductive organs are verbally metaphorised twice in Text 2, one as a general location and the other as the route of childbirth.

5. An intermediate language system that young children use in order to learn Chinese characters.

6. The name, which is translated from "Willy", literally means "little powerful" in Chinese and is commonly used as boys' name.

\section{REFERENCES}

Aresu, A. (2009). Sex education in modern and contemporary China: Interrupted debates across the last century. International Journal of Educational Development, 29, 532-541. Aubusson, P. J., Harrison, A. G., \& Ritchie, S. M. (Eds.) (2006). Metaphor and analogy in science education. Dordrecht: Springer.

Berlant, L., \& Warner, M. (1998). Sex in public. Critical Inquiry, 24(2), 547-566.

Bounegru, L., \& Forceville, C. (2011). Metaphors in editorial cartoons representing the global financial crisis. Visual Communication, 10(2), 209-229.

Britzman, D. (1998). Lost subjects, contested objects: Toward a psychoanalytic inquiry of learning. Albany: State University of New York Press.

Cameron, L. (2003). Metaphor in educational discourse. London \& New York: Continuum.

De Saussure, F. (1966). Course in general linguistics. New York: McGraw Hill.

Duit, R. (1991). On the role of analogies and metaphors in learning science. Science Education, 75(6), 649-672. 
Forceville, C. (1994). Pictorial metaphor in advertisements. Metaphor and Symbolic Activity, $9(1), 1-29$.

Forceville, C. (1996). Pictorial metaphor in advertising. London \& New York: Routledge.

Forceville, C. (2009). Non-verbal and multimodal metaphor in a cognitivist framework:

Agendas for research. In C. Forceville \& E. Urios-Aparisi (Eds.) (pp. 19-42).

Forceville, C., \& Urios-Aparisi, E. (2009). Introduction. In C. Forceville \& E. Urios-Aparisi (Eds.) (pp. 3-17).

Forceville, C., \& Urios-Aparisi, E. (Eds.) (2009). Multimodal metaphor. Berlin \& New York: Mouton de Gruyter.

Gibbs, R. W. (2006). Embodiment and cognitive science. Cambridge: Cambridge University Press.

Goffman, E. (1979). Gender advertisements. New York: Harper \& Row.

Halliday, M. A. K. (2014). An introduction to functional grammar (4th edn). London: Arnold. Higgins, L., Zheng, M., Liu, Y., \& Sun, C. (2002). Attitudes to marriage and sexual behaviours: A survey of gender and cultural differences in China and United Kingdom. Sex Roles, 46(3/4), 75-89.

Inagaki, K., \& Hatano, G. (1987). Young children's spontaneous personification as analogy. Child Development, 58(4), 1013-1020.

Jankowiak, W. R., \& Fischer, E. F. (1992). A cross-cultural perspective on romantic love. Ethnology, 31(2), 149-155.

Johnson, M. (1987). The body in the mind: The bodily basis of meaning, imagination, and reason. Chicago: The University of Chicago Press.

Lakoff, G. (1988). Cognitive semantics. In U. Eco, M. Santambrogio \& P. Violi (Eds.), Meaning and mental representations (pp. 119-154). Bloomington, IN: Indiana University Press. 
Lakoff, G., \& Johnson, M. (1980). Metaphors we live by. Chicago: The University of Chicago Press.

Lakoff, G., \& Johnson, M. (1999). Philosophy in the flesh: The embodiment mind and its challenge to western thought. New York: Basic Books.

Liang, J. Y., Tan, S. \& O’Halloran, K. (2016) Representing sexuality and morality in sex education picture books in contemporary China. Social Semiotics. Doi: http://dx.doi.org/10.1080/10350330.2016.1161117.

Liu, W. (2008). 1988 - 2007: A review of research on teenager sex education in China.[in Chinese]. China Youth Study, 3, 50-57.

Liu, W., \& Su, Y. (2014). School-based primary school sexuality education for migrant children in Beijing, China. Sex Education, 14(5), 568-581.

Lupton, D. (2003). Medicine as culture: Illness, disease and the body in western societies (2nd edn). London, Thousand Oaks, \& New Delhi: Sage.

MacKay, D. G. (1986). Prototypicality among metaphors: On the relative frequency of personification and spatial metaphors in literature written for children versus adults. Metaphor and Symbolic Activity, 1(2), 87-107.

Martin, E. (1991). The egg and the sperm: How science has constructed a romance based on stereotypical male-female roles. Signs: Journal of Women in Culture and Society, $16(3), 485-501$.

Martin, E. (2001). The woman in the body: A cultural analysis of reproduction. Boston: Beacon Press.

Morris, R. (1993). Visual rhetoric in political cartoons: A structuralist approach. Metaphor and Symbolic Activity, 8(3), 195-210.

Pan, S. (1994). A sexual revolution in current China. Journal of Psychology \& Human Sexuality, 6(2), 1-14. 
Sandlos, K. (2010). On the aesthetic difficulties of research on sex education: Towards a methodology of affect. Sex Education, 10(3), 299-308.

Schatten, G., \& Schaten, H. (1984). The energetic egg. Medical World News, 23, 51-53.

Stone, N., Ingham, R., \& Gibbins, K. (2013). 'Where do babies come from?' Barriers to early sexuality communication between parents and young children. Sex Education: Sexuality, Society and Learning, 13(2), 228-240.

The Biology and Gender Study Group (1988). The importance of feminist critique for contemporary cell biology. Hypatia, 3(1), 61-76.

Urios-Aparisi, E. (2010). The Body of love in Almodóvar's cinema: Metaphor and metonymy of the body and body parts. Metaphor and Symbol, 25(3), 181-203.

Vosniadou, S. (1987). Children and Metaphor. Child Development, 58(3), 870-885.

$\mathrm{Yu}, \mathrm{N}$. (2008). The Chinese heart as the central faculty of cognition. In F. Sharifian, R. Dirven, N. Yu \& S. Niemeier (Eds.), Culture, body and language: Conceptualisations of internal body organs across cultures and languages (pp. 131-168). Berlin \& New York: Mouton de Gruyter. 